\title{
PRAWNE UWARUNKOWANIA PRZEDSIĘBIORCZOŚCI W POLSCE W OKRESIE ŚWIATOWEGO KRYZYSU EKONOMICZNEGO
}

\section{WSTĘP}

Wśród przyczyn światowego kryzysu ekonomicznego, dotkliwie odczuwanego przez wiele gospodarek dotkniętych spadkiem produkcji i wzrostem rozmiarów bezrobocia, wymienia się nadmierną aktywność przedsiębiorstw sektora finansowego (banków, ubezpieczycieli, podmiotów zajmujących się obrotem nieruchomościami, podmiotów rynku kapitałowego) kreujących szkodliwe ekonomicznie (toksyczne) produkty i usługi ${ }^{1}$. Aktywność ta jest niewątpliwie przejawem przedsiębiorczości, mającym jednak negatywne skutki dla sfery realnej gospodarki. Przedsiębiorczość w sferze realnej gospodarki jest z kolei jednym z podstawowych czynników rozwoju społeczno-gospodarczego. Może być więc sposobem na złagodzenie kryzysu ekonomicznego, usuwanie jego skutków i przeciwdziałanie kolejnym spadkom koniunktury.

Rozmiary i efekty przedsiębiorczości w danym kraju zależą nie tylko od cech osobowościowych przedsiębiorców, które sprawiają, że są oni bardziej lub mniej aktywni gospodarczo i wykazują większą lub mniejszą skłonność do podejmowania ryzyka związanego z prowadzeniem działalności gospodarczej. Są one także w dużej mierze uzależnione od okoliczności, w których prowadzona jest ta działalność, a które tworzy szereg uwarunkowań o charakterze zarówno lokalnym (regionalnym), jak i makroekonomicznym. Wśród uwarunkowań

${ }^{2}$ J. Famielec, Kryzys finansowy a rozwoój przedsiębiorczości, [w:] K. Jaremczuk (red.), Uwarunkowania przedsiębiorczości. Różnorodność i jedność, t. 2, Wydawnictwo Państwowej Wyższej Szkoły Zawodowej im. prof. Stanisława Tarnowskiego w Tarnobrzegu, Tarnobrzeg 2010, s. 327. 
lokalnych można wymienić politykę władz lokalnych (regionalnych), warunki lokalizacyjne, kapitał zaufania społecznego i edukację. Do uwarunkowań makroekonomicznych zalicza się z kolei czynniki polityczne, prawne, ekonomiczne, społeczne, kulturowe i komunikacyjne ${ }^{2}$.

Wydaje się, że w okresie znacznego spowolnienia gospodarczego kluczowym czynnikiem ułatwiającym wyzwolenie sił tkwiących w przedsiębiorstwach są zmiany w prawie gospodarczym polegające na redukcji nadmiernych obciążeń finansowych i biurokratycznych oraz usuwaniu barier będących przeszkodą dla rozwoju przedsiębiorczości. Należą one do działań o stosunkowo niskich kosztach, a ich efekty w postaci ułatwień w zakresie rozpoczynania i prowadzenia działalności gospodarczej mogą stanowić istotny impuls prorozwojowy dla gospodarki.

Przedmiotem opracowania jest analiza zmian w polskim prawie określającym zasady prowadzenia działalności gospodarczej wprowadzonych w latach 2008-2010. Szczególną uwagę zwrócono na te zmiany, które mogą ułatwić przedsiębiorcom rozpoczęcie i prowadzenie działalności w okresie dekoniunktury oraz skłonić ich do intensyfikacji aktywności gospodarczej skutkującej poprawą ogólnej sytuacji społeczno-ekonomicznej w kraju. Opracowanie ma zarówno cel poznawczy, jak i aplikacyjny. Cel poznawczy polega na zidentyfikowaniu i scharakteryzowaniu zmian wprowadzonych do aktów prawnych ważnych $\mathrm{z}$ punktu widzenia rozwoju przedsiębiorczości w Polsce w latach 2008-2010. Cel aplikacyjny polega natomiast na zaprezentowaniu możliwości wykorzystania tych zmian przez przedsiębiorstwa doświadczające trudności w prowadzeniu działalności gospodarczej, a także stojące w obliczu niebezpieczeństwa upadku w okresie spowolnienia gospodarczego w Polsce, będącego skutkiem i przejawem światowego kryzysu ekonomicznego.

\section{„PAKIET NA RZECZ PRZEDSIĘBIORCZOŚCI” JAKO INSTRUMENT UPRASZCZANIA OTOCZENIA REGULACYJNEGO PRZEDSIĘBIORSTW}

W okresie 2008-2010 szczególnie istotne, z punktu widzenia przeciwdziałania skutkom kryzysu gospodarczego w Polsce, było tworzenie przyjaznego środowiska instytucjonalnego przedsiębiorczości w ramach realizacji „Pakietu na rzecz przedsiębiorczości” będącego elementem tzw. reformy regulacji. Dzia-

${ }^{3}$ K. Safin, Uwarunkowania rozwoju przedsiębiorczości - próba systematyzacji, [w:] K. Jaremczuk (red.), Uwarunkowania przedsiębiorczości, Wydawnictwo Państwowej Wyższej Szkoły Zawodowej im. prof. Stanisława Tarnowskiego w Tarnobrzegu, Tarnobrzeg, 2004, s. 47-54. 
łania podejmowane w tym zakresie przez państwo są elementem Krajowego Programu Reform na lata 2008-2011 (dalej: KPR) - dokumentu, w którym przedstawiono inicjatywy, jakie polski rząd zamierza podjąć dla realizacji odnowionej Strategii Lizbońskiej³.

Celem reform wprowadzanych w ramach KPR jest stworzenie podstaw do trwałego rozwoju gospodarczego, któremu będzie towarzyszyła poprawa jakości życia społeczeństwa. Jednym z warunków realizacji tego celu jest stworzenie przyjaznego otoczenia prawnego dla przedsiębiorczości poprzez redukcję obciążeń administracyjnych nakładanych przez prawo na przedsiębiorców oraz znoszenie barier prawnych w rozwoju przedsiębiorczości ${ }^{4}$. Bariery administracyjne oraz uciążliwości prawne krępujące przedsiębiorczość, hamując potencjał rozwojowy przedsiębiorstw są barierą wzrostu gospodarczego w Polsce.

Upraszczanie istniejącego prawa oraz lepsze stanowienie nowych regulacji prawnych prowadzone w ramach „Pakietu na rzecz przedsiębiorczości” ma na celu ułatwienie podejmowania i prowadzenia działalności gospodarczej. Nowelizacje ustaw wchodzących w skład „Pakietu na rzecz przedsiębiorczości” dotyczące przede wszystkim szeroko pojętego prawa gospodarczego oraz podatkowego mają przyczynić się do stworzenia otoczenia regulacyjnego przyjaznego przedsiębiorstwom, w tym zwłaszcza z sektora MŚP. Obejmują one zmiany w takich obszarach ich aktywności, jak: dostęp do kapitału, komercjalizacja technologii, prowadzenie działalności badawczo-rozwojowej oraz tworzenie przedsiębiorstw technologicznych. Wiążą się z likwidowaniem zbędnych bądź dublujących się zapisów, zmniejszaniem reglamentacji działalności gospodarczej (ograniczaniem konieczności uzyskiwania koncesji, licencji i zezwoleń na prowadzenie działalności gospodarczej), zwiększaniem swobody działalności gospodarczej oraz poprawą przejrzystości i jednoznaczności obowiązujących przepisów ${ }^{5}$.

${ }^{4}$ Od marca 2010 r. Strategię Lizbońską zastąpiła strategia „Europa 2020” - nowy, długookresowy program rozwoju społeczno-gospodarczego Unii Europejskiej, będący odpowiedzią na znaczne spowolnienie gospodarcze krajów członkowskich tego ugrupowania oraz obniżenie jego konkurencyjności. Instrumentami realizacji strategii „Europa 2020” są Krajowe Programy Reform opracowane przez państwa członkowskie UE oraz tzw. inicjatywy przewodnie przygotowane przez Komisję Europejską. Krajowe Programy Reform na rzecz realizacji strategii „Europa 2020” mają być przekazane Komisji Europejskiej w kwietniu 2011 r. Powinny one zawierać propozycje działań służących budowaniu trwałych podstaw wzrostu gospodarczego, realizujących zarówno cele unijne, jak i krajowe.

${ }_{5}$ Krajowy Program Reform na lata 2008-2011 na rzecz realizacji Strategii Lizbońskiej, Ministerstwo Gospodarki, Warszawa 2008, s. 4, 23, http:/www.mg.gov.p1/NR/rdonlyres/ED3609C21747-4125-98B1-C23D09115D94/49494/KrajowyProgramReformna lata20082011.pdf.

${ }^{6}$ Raport z realizacji dziatań Reformy Regulacji w 2009 roku, Ministerstwo Gospodarki, Warszawa 2010, s. 6, http://www.mg.gov.p1/files/upload/8668/publikacja_5.pdf. 


\section{REALIZACJA \\ "PAKIETU NA RZECZ PRZEDSIĘBIORCZOŚCI" W 2008 ROKU}

Najważniejsze zmiany w prawie mające na celu ułatwienie zakładania i prowadzenia działalności gospodarczej w Polsce wprowadzone w 2008 roku przedstawiono w tabeli 1 .

Tabela 1. Zmiany w ustawach określających zasady prowadzenia działalności gospodarczej w Polsce wprowadzone w ramach realizacji „Pakietu na rzecz przedsiębiorczości” w 2008 r.

\begin{tabular}{|c|c|}
\hline WYSZCZEGÓLNIENIE & NAJWAŻNIEJSZE ZMIANY \\
\hline $\begin{array}{l}\text { Ustawa } \\
\text { o swobodzie } \\
\text { działalności gospodarczej }\end{array}$ & $\begin{array}{l}\text { - wprowadzenie możliwości zawieszenia działalności gospodarczej na okres od } \\
\text { miesiąca do } 2 \text { lat, } \\
\text { - rozszerzenie możliwości wydawania wiążących interpretacji prawa, } \\
\text { - wprowadzenie obowiązku przyjęcia przez urzędnika niekompletnych dokumen- } \\
\text { tów, } \\
\text { - wprowadzenie zakazu żądania przez urzędników dokumentów niewymaganych } \\
\text { prawem, } \\
\text { - obniżenie opłaty za wydanie interpretacji prawa z } 75 \text { zł do } 40 \text { zł, }\end{array}$ \\
\hline Ustawa o rachunkowości & $\begin{array}{l}\text { - podniesienie progu przychodów zobowiązujących do prowadzenia pełnej księgo- } \\
\text { wości z } 800 \text { tys. euro do 1,2 mln euro, }\end{array}$ \\
\hline Ordynacja podatkowa & $\begin{array}{l}\text { - wprowadzenie zasady domniemania uczciwości podatnika, } \\
\text { - zwolnienie najmniejszych przedsiębiorców z obowiązku posiadania dodatkowe- } \\
\text { go rachunku bankowego do opłacania podatków; możliwość opłacania składek } \\
\text { na ubezpieczenie społeczne za pomocą przekazu pocztowego, } \\
\text { - zniesienie solidarnej odpowiedzialności dz ierżawców (użytkowników) nierucho- } \\
\text { mości i jej właściciela za zaległe podatki od nieruchomości, } \\
\text { - zniesienie odpowiedzialności wspólnika za osobiste zobowiązania podatkowe } \\
\text { pozostałych wspólników wynikające z działalności spółki; odpowiedzialność } \\
\text { wspólnika odnosi się tylko do zobowiązań podatkowych spółki, } \\
\text { - wprowadzenie obowiązku poinformowania podatnika o wszczęciu kontroli jego } \\
\text { działalności z 7-dniowym wyprzedzeniem, }\end{array}$ \\
\hline $\begin{array}{l}\text { Ustawa } \\
\text { o podatku dochodowym } \\
\text { od osób fizycznych; } \\
\text { ustawa } \\
\text { o podatku dochodowym } \\
\text { od osób prawnych }\end{array}$ & $\begin{array}{l}\text { - wprowadzenie możliwości wpłacania zaliczek na podatek dochodowy co kwar- } \\
\text { tał w przypadku małych podatników oraz rozpoczynających prowadzenie dzia- } \\
\text { talności gospodarczej, } \\
\text { - wprowadzenie możliwości zaliczenia do kosztów podatkowych wydatków ponie- } \\
\text { sionych na inwestycje do wysokości } 100 \text { tys. euro, w postaci jednorazowo do- } \\
\text { konywanych odpisów amortyzacyjnych, }\end{array}$ \\
\hline $\begin{array}{c}\text { Ustawa } \\
\text { o izbach gospodarczych }\end{array}$ & $\begin{array}{l}\text { - zwiększenie swobody samoorganizowania się przedsiębiorców w izbach gospo- } \\
\text { darczych, } \\
\text { - wprowadzenie możliwości uzyskania osobowości prawnej przez jednostki tere- } \\
\text { nowe izb gospodarczych, }\end{array}$ \\
\hline $\begin{array}{l}\text { Prawo dewizowe } \\
\text { i Kodeks cywilny }\end{array}$ & $\begin{array}{l}\text { - wprowadzenie możliwości dokonywania rozliczeń i prowadzenia rachunków } \\
\text { w walutach wymienialnych, bez konieczności uzyskania zezwolenia Prezesa Na- } \\
\text { rodowego Banku Polskiego, }\end{array}$ \\
\hline
\end{tabular}


Ciąg dalszy tabeli 1.

\begin{tabular}{|c|c|}
\hline WYSZCZEGÓLNIENIE & NAJWAŻNIEJSZE ZMIANY \\
\hline $\begin{array}{l}\text { Kodeks } \\
\text { spółek handlowych }\end{array}$ & $\begin{array}{l}\text { - obniżenie minimalnego kapitału zakładowego w spółkach z ograniczoną odpo- } \\
\text { wiedzialnością z } 50 \text { tys. zł do } 5 \text { tys. zł, a w spółkach akcyjnych z } 500 \text { tys. zł do } \\
100 \text { tys. zł, } \\
\text { - zniesienie obowiazzku przekształcania spółek cywilnych w spótki jawne w przy- } \\
\text { padku, gdy przychody netto spółki cywilnej w każdym z dwóch ostatnich lat } \\
\text { osiągnęły wartość, która zobowiązuje przedsiębiorstwo do prowadzenia ksiąg } \\
\text { rachunkowych, } \\
\text { - ograniczenie odpowiedzialności wspólników spółki jawnej za długi przedsiębior- } \\
\text { stwa wniesionego aportem przez jednego ze wspólników do majątku spółki - } \\
\text { wspólnicy odpowiadają za zobowiązania przedsiębiorstwa tylko do jego warto- } \\
\text { ści w chwili wniesienia go do spółki, } \\
\text { - ograniczenie wymogów formalnych dla jednoosobowych spółek kapitałowych - } \\
\text { wspólnicy lub akcjonariusze nie muszą notarialnie poświadczać podpisu składa- } \\
\text { nego na oświadczeniach woli, } \\
\text { - precyzyjne określenie dnia wypłaty dywidendy w spółkach kapitałowych - o ter- } \\
\text { minie tym decydują organy spółki; urzędy skarbowe nie mogą już interpretować } \\
\text { opóźnienia wypłaty jako świadczenia wspólników na rzecz spółki i żądać z tego } \\
\text { tytułu podatku, } \\
\text { - skrócenie z trzech do jednego miesiąca okresu zwrotu dopłat z tytułu straty wy- } \\
\text { kazanej w sprawozdaniu finansowym spółki, } \\
\text { - ograniczenie obowiązków spółek akcyjnych w zakresie podawania do publicznej } \\
\text { wiadomości uchwał i sprawozdań (dot. m.in. obowiązku ogłaszania w Monito- } \\
\text { rze Sądowym i Gospodarczym uchwał WZA obradujących w trybie art. 405, tj. } \\
\text { bez formalnego zwołania), } \\
\text { - obniżenie kary nakładanej na członków zarządów spółek handlowych za złożenie } \\
\text { niekompletnego zamówienia handlowego lub innych informacji, o których mowa } \\
\text { w art. } 127 \text { § } 5 \text { z z } 10 \text { tys. zł do } 5 \text { tys. zł, }\end{array}$ \\
\hline \begin{tabular}{|c|} 
Ustawa \\
o niektórych formach wspierania \\
działalności innowacyjnej
\end{tabular} & $\begin{array}{l}\text { - zwiększono możliwość wsparcia przedsięwzięć innowacyjnych środkami prywat- } \\
\text { nymi, }\end{array}$ \\
\hline $\begin{array}{l}\text { Ustawa o specjalnych strefach } \\
\text { ekonomicznych }\end{array}$ & $\begin{array}{l}\text { - podwyższono limit obszarów objętych specjalnymi strefami ekonomicznymi do } \\
20 \text { tys. ha, } \\
\text { - uściślono kryteria włączania gruntów prywatnych do specjalnych stref ekono- } \\
\text { micznych, } \\
\text { - złagodzono przepisy dotyczące możliwych zmian w zezwoleniach na prowadze- } \\
\text { nie działalności w strefie. }\end{array}$ \\
\hline
\end{tabular}

Źródło: Ministerstwo Gospodarki, http://www.mg.gov.pl; Ustawa z dnia 10 lipca 2008 r. o zmianie ustawy o swobodzie działalności gospodarczej oraz o zmianie niektórych innych ustaw, Dz.U. 2008, Nr 141, poz. 888; Ustawa z dnia 10 lipca 2008 r. o zmianie ustawy o rachunkowości, Dz.U. 2008, Nr 144, poz. 900; Ustawa z dnia 6 listopada 2008 r. o zmianie ustawy o podatku dochodowym od osób fizycznych, ustawy o podatku dochodowym od osób prawnych oraz niektórych innych ustaw, Dz.U. 2008, Nr 209, poz. 1316; Ustawa z dnia 7 listopada 2008 r. o zmianie ustawy o izbach gospodarczych, Dz.U. 2008, Nr 216, poz. 1369; Ustawa z dnia 23 października 2008 r. o zmianie ustawy - Kodeks cywilny oraz ustawy - Prawo dewizowe, Dz.U. 2008, Nr 228, poz. 1506; Ustawa z dnia 23 października 2008 r. o zmianie ustawy Kodeks spótek handlowych, Dz.U. 2008, Nr 217, poz. 1381; Ustawa z dnia 30 maja 2008 r. o niektórych formach wspierania działalności innowacyjnej, Dz.U. 2008, Nr 116, poz. 730; Ustawa z dnia 30 maja 2008 r. o zmianie ustawy o specjalnych strefach ekonomicznych, Dz.U. 2008 nr 118 poz. 746. 
Za najważniejsze z punktu widzenia wspierania przedsiębiorczości w Polsce w okresie kryzysu należy uznać zmiany dotyczące: możliwości zawieszania działalności gospodarczej na okres od miesiąca do 2 lat bez konieczności ponoszenia w tym czasie kosztów funkcjonowania przedsiębiorstwa, podniesienia progu przychodów zobowiązujących do prowadzenia pełnej księgowości, częstotliwości wpłacania zaliczek na podatek dochodowy przez tzw. małych podatników, zaliczania do kosztów podatkowych wydatków poniesionych na inwestycje, dokonywania rozliczeń i prowadzenia rachunków w walutach wymienialnych, obniżenia minimalnego kapitału zakładowego $\mathrm{w}$ spółkach z ograniczoną odpowiedzialnością i spółkach akcyjnych, zasad wspierania przedsięwzięć innowacyjnych oraz funkcjonowania specjalnych stref ekonomicznych.

Możliwość zawieszenia działalności gospodarczej na okres od miesiąca do dwóch lat, z opcją wydłużenia tego okresu, bez konieczności wypełniania w okresie zawieszenia obowiązków związanych z funkcjonowaniem przedsiębiorstwa jest rozwiązaniem korzystnym zwłaszcza w czasie dekoniunktury, kiedy przedsiębiorcy stykają się z problemem spadku liczby zamówień i realną groźbą utraty płynności finansowej, a także wypłacalności. Rozwiązanie to nie wiąże się z zagrożeniem utraty pracy przez pracowników, ponieważ przewidziane zostało jedynie dla przedsiębiorców prowadzących działalność gospodarczą jednoosobowo. Dla wielu z nich może stanowić szansę na wykorzystanie posiadanego potencjału ekonomicznego w czasie, gdy w gospodarce, po okresie spowolnienia, pojawią się oznaki ożywienia. W wielu przypadkach nie byłoby to możliwe, gdyby zawieszenie działalności wiązało się z koniecznością ponoszenia kosztów prowadzenia księgowości, składania deklaracji i sprawozdań podatkowych oraz ZUS, uiszczania podatków, opłacania zaliczek na podatki i składek ubezpieczeniowych. Brak możliwości wypełniania tych obowiązków ze względu na słabą kondycję finansową oznaczałby często konieczność likwidacji przedsiębiorstwa.

Skutecznym instrumentem poprawy, a niekiedy nawet utrzymania płynności finansowej przedsiębiorstwa w jednym z najtrudniejszych okresów jego funkcjonowania, tzn. w momencie rozpoczynania działalności gospodarczej lub w czasie spowolnienia gospodarczego, może być także kwartalny sposób opłacania zaliczek na podatek dochodowy. Oprócz podatników rozpoczynających prowadzenie działalności gospodarczej, mogą z niego skorzystać tzw. mali podatnicy, czyli przedsiębiorcy, których wartość osiągniętych przychodów ze sprzedaży wraz z kwotą podatku VAT nie przekroczyła w poprzednim roku podatkowym wyrażonej w złotych równowartości $1,2 \mathrm{mln}$ euro.

Podwyższenie ustawowego progu przychodów, zobowiązującego do prowadzenia pełnej księgowości, z kwoty 800 tys. euro do 1,2 mln euro skutkuje obniżeniem kosztów prowadzenia działalności gospodarczej, związanych nie 
tylko z koniecznością zatrudniania osób, które posiadają uprawnienia do prowadzenia ksiąg, ale także z licznymi obowiązkami sprawozdawczymi, którymi obarczony jest podmiot prowadzący pełną księgowość. Zmiana ta może również skłonić przedsiębiorców, którzy ukrywają część swoich przychodów z obawy o konieczność ponoszenia dodatkowych kosztów funkcjonowania, do ich ujawnienia, a tym samym do zmniejszenia rozmiarów szarej strefy.

Typowo antykryzysowy charakter miał przepis wprowadzony przez ustawy o podatku dochodowym od osób fizycznych i prawnych dotyczący zaliczania do kosztów podatkowych wydatków poniesionych na inwestycje. Mogły z niego skorzystać podmioty podejmujące działalność gospodarczą w latach 2008-2010 oraz mali podatnicy funkcjonujący na rynku w latach 2009-2010. Nakłady ponoszone przez te przedsiębiorstwa w związku z zakupem maszyn, urządzeń, wyposażenia itp. mogły być zaliczone do kosztów podatkowych do wysokości 100 tys. euro w postaci jednorazowo dokonywanych odpisów amortyzacyjnych. Skutkowało to zmniejszeniem podstawy opodatkowania, a tym samym kwoty podatku, poprawiając płynność finansową przedsiębiorstwa. Była to także zachęta do aktywności inwestycyjnej, która w okresie dekoniunktury uległa wyhamowaniu ze względu na ograniczone możliwości finansowania inwestycji, w tym również z coraz trudniej dostępnych źródeł zewnętrznych.

Dokonywanie rozliczeń i prowadzenie rachunków w walutach obcych bez konieczności uzyskania zezwolenia Prezesa Narodowego Banku Polskiego może być znaczącym ułatwieniem dla polskich przedsiębiorstw prowadzących działalność importową i eksportową, dla których wahania kursu złotego np. wobec euro wiążą się z większym ryzykiem kursowym i większymi kosztami zabezpieczania takich transakcji, a przez to również (w przypadku eksporterów) z mniejszą konkurencyjnością ich produkcji na rynkach zagranicznych.

Obniżenie minimalnego kapitału zakładowego w spółkach $\mathrm{z}$ ograniczoną odpowiedzialnością i akcyjnych oznacza zdecydowanie niższe koszty związane $\mathrm{z}$ rozpoczęciem działalności gospodarczej dla przedsiębiorców zamierzających prowadzić działalność w ramach takiej formy prawnej. Forma spółki Z ograniczoną odpowiedzialnością i spółki akcyjnej stała się więc bardziej dostępna dla najmniejszych przedsiębiorców chcących skorzystać z jej zalet, lecz niedysponujących dużymi zasobami finansowymi (minimalny kapitał zakładowy konieczny do rejestracji spółki z ograniczoną odpowiedzialnością w rejestrze przedsiębiorców został obniżony z 50 tys. zł do 5 tys. zł, a spółki akcyjnej -z 500 tys. zł do 100 tys. zł). Spodziewanym skutkiem tej zmiany jest zwiększenie liczby spółek kapitałowych oraz poprawa konkurencyjności Polski na rynku europejskim pod względem warunków uruchamiania działalności $\mathrm{w}$ takich formach prawnych, również przez podmioty zagraniczne. Obniżenie 
minimalnego kapitału zakładowego, zwłaszcza w spółkach z ograniczoną odpowiedzialnością, może mieć także negatywne konsekwencje. W okresie dekoniunktury, kiedy duża część przedsiębiorstw odczuwa trudności w terminowym regulowaniu zobowiązań, roszczenia wierzycieli, do pokrycia których ostatecznie służy kapitał zakładowy, mogą pozostać niezaspokojone z powodu symbolicznej wartości tego kapitału.

Zwiększenie możliwości wsparcia przedsięwzięć innowacyjnych środkami prywatnymi oznacza m.in. udzielanie przedsiębiorstwom kredytu technologicznego przez banki komercyjne oraz udział w jego spłacie (w postaci premii technologicznej) Banku Gospodarstwa Krajowego. Wiąże się to ze zwiększeniem podaży tego instrumentu finansowego, a tym samym jego dostępności, co w warunkach ograniczonych możliwości finansowania działalności inwestycyjnej w ogóle, a innowacyjnej w szczególności, jest ważnym działaniem z punktu widzenia rozwoju przedsiębiorczości.

Nowelizacja ustawy o specjalnych strefach ekonomicznych była odpowiedzią na duże zainteresowanie inwestorów, w tym również zagranicznych, lokowaniem kapitału na terenach objętych ekonomicznymi przywilejami. Mając na uwadze korzyści dla regionu i kraju ze wzrostu wartości kapitału ulokowanego w strefach, zwiększono ich powierzchnię z 12 tys. ha do 20 tys. ha. Nowelizacja tej ustawy była również odpowiedzią na spadek dynamiki inwestycji dokonywanych w strefach i ograniczone możliwości wywiązywania się inwestorów ze zobowiązań określonych w zezwoleniach na prowadzenie działalności gospodarczej na terenie strefy. Złagodzenie przepisów dotyczących zmian w zezwoleniach ma uchronić przedsiębiorstwa działające w strefach przed utratą tych zezwoleń ze względu na trudności w zrealizowaniu określonego pułapu nakładów inwestycyjnych lub zatrudnieniu zadeklarowanej liczby nowych pracowników. Warunki zezwolenia mogą zostać zmienione na korzystniejsze, jeżeli nie zostanie obniżony poziom zatrudnienia w stosunku do poziomu ustalonego w zezwoleniu o więcej niż 20\%, zmiana zezwolenia nie będzie wiązała się ze zwiększeniem pomocy publicznej oraz nie będzie dotyczyła spełnienia warunków określonych dla inwestycji realizowanych na gruntach należących do terenu stref i będących własnością osób prywatnych.

\section{REALIZACJA „PAKIETU NA RZECZ PRZEDSIĘBIORCZOŚCI" W 2009 ROKU}

W 2009 roku w ramach reformy regulacji dokonano kolejnych nowelizacji ustaw mających na celu zmniejszenie uciążliwości prawa gospodarczego, a tym 
samym tworzenie bardziej przyjaznego dla przedsiębiorców otoczenia regulacyjnego (tabela 2). Zmiany te wprowadzono z myślą o zabezpieczeniu przedsiębiorstw na wypadek niewypłacalności ich dłużników, zwiększeniu stopnia wykorzystania tkwiącego w nich potencjału oraz pobudzeniu aktywności inwestycyjnej w gospodarce dotkniętej kryzysem.

Tabela 2. Zmiany w ustawach określających zasady prowadzenia działalności gospodarczej w Polsce wprowadzone w ramach realizacji „Pakietu na rzecz przedsiębiorczości” w 2009 r.

\begin{tabular}{|c|c|}
\hline WYSZCZEGÓLNIENIE & NAJWAŻNIEJSZE ZMIANY \\
\hline $\begin{array}{c}\text { Ustawa } \\
\text { o swobodzie } \\
\text { działalności gospodarczej }\end{array}$ & $\begin{array}{l}\text { - wprowadzenie tzw. „jednego okienka”, w którym można dokonać wszelkich for- } \\
\text { malności związanych z rozpoczęciem działalności gospodarczej, } \\
\text { - uproszczenie i ograniczenie czasu oraz zasad kontroli przedsiębiorców, }\end{array}$ \\
\hline $\begin{array}{l}\text { Prawo upadłościowe } \\
\text { i naprawcze }\end{array}$ & $\begin{array}{l}\text { - wprowadzenie tzw. upadłości konsumenckiej - upadłości osoby fizycznej nie bę- } \\
\text { dącej przedsiębiorcą, która stała się niewypłacalna na skutek wyjątkowych i nie- } \\
\text { zależnych od niej okoliczności, }\end{array}$ \\
\hline $\begin{array}{l}\text { Ustawa o partnerstwie } \\
\text { publiczno-prywatnym }\end{array}$ & $\begin{array}{l}\text { - wprowadzenie możliwości realizowania przedsięwzięć w formule partnerstwa pub- } \\
\text { liczno-prywatnego bez zbędnych obciążeń administracyjnych i nadmiernych ograni- } \\
\text { czeń, z zapewnieniem stronom umowy swobody w zakresie wyboru form współ- } \\
\text { pracy i rodzaju realizowanych projektów, } \\
\text { - ograniczenie wymogu uzyskania zgody Ministra Finansów na realizację projektów } \\
\text { w ramach partnerstwa publiczno-prywatnego do przedsięwzięć, które wiążą się } \\
\text { z zaangażowaniem środków budżetowych w wysokości przekraczającej } 100 \text { mln zł, }\end{array}$ \\
\hline $\begin{array}{c}\text { Ustawa } \\
\text { o towarach paczkowanych }\end{array}$ & $\begin{array}{l}\text { - doprecyzowanie niezbędnych i zniesienie zbędnych obowiązków przedsiębiorców } \\
\text { paczkujących lub wprowadzających do obrotu towary paczkowane, } \\
\text { - wyłączenie z nadzoru administracji miar towarów oznakowanych znakiem „e" na } \\
\text { terytorium UE, } \\
\text { - zwolnienie producentów aerozoli z konieczności przestrzegania ściśle określonych } \\
\text { pojemności opakowań, }\end{array}$ \\
\hline $\begin{array}{c}\text { Ustawa } \\
\text { o praktykach absolwenckich }\end{array}$ & $\begin{array}{l}\text { - określenie zasad przyjmowania absolwentów na staż i praktyki w celu uzyskania } \\
\text { doświadczenia zawodowego; zniesienie wymogów administracyjnych i biurokra- } \\
\text { tycznych odbywania praktyk, }\end{array}$ \\
\hline
\end{tabular}

Źródło: Ministerstwo Gospodarki, http://www.mg.gov.pl; Ustawa z dnia 19 grudnia 2008 r. o zmianie ustawy o swobodzie działalności gospodarczej oraz o zmianie niektórych innych ustaw, Dz.U. 2009, Nr 18, poz. 97; Ustawa z dnia 5 grudnia 2008 r. o zmianie ustawy Prawo upadłościowe i naprawcze oraz ustawy o kosztach sądowych w sprawach cywilnych, Dz.U. 2008, Nr 234, poz. 1572; Ustawa z dnia 19 grudnia 2008 r. o partnerstwie publiczno-prywatnym, Dz.U. 2009, Nr 19, poz. 100; Ustawa z dnia 7 maja 2009 r. o towarach paczkowanych, Dz.U. 2009, Nr 91, poz. 740; Ustawa z dnia 17 lipca 2009 r. o praktykach abso/wenckich, Dz.U. 2009, Nr 127, poz. 1052.

Jedną z ważniejszych zmian w prawie gospodarczym w 2009 roku było wprowadzenie tzw. ,jednego okienka”, dzięki któremu osoby zamierzające otworzyć działalność gospodarczą mogą złożyć jeden wniosek o rejestrację tej działalności, zamiast wcześniej obowiązujących czterech, dopełniając tym samym wszelkich formalności rejestracyjnych. Taki system rejestracji ma 
charakter przejściowy. Docelowo (od 1 lipca 2011 r.) ma obowiązywać zasada „zero okienka” zgodnie z którą rejestracja działalności gospodarczej będzie odbywała się przez Internet, bez konieczności wizyty w urzędzie. Rozwiązania te uproszczą i przyspieszą proces rozpoczynania działalności gospodarczej, eliminując jednocześnie część kosztów z tym związanych. Ograniczenie kosztów prowadzenia działalności gospodarczej jest również oczekiwane w związku ze zmianą zasad przeprowadzania kontroli w przedsiębiorstwach. Skróceniu uległ bowiem czas trwania tych kontroli, a ponadto wprowadzono zakaz jednoczesnego prowadzenia więcej niż jednej kontroli i sankcje wobec instytucji kontrolującej w przypadku kontroli niezgodnej z prawem. Istotna zmiana dotyczy także określenia przedmiotu kontroli. Nie powinien być nim przedsiębiorca, lecz wykonywana przez niego działalność gospodarcza.

Pomocne w utrzymaniu płynności finansowej przedsiębiorstw, zwłaszcza $\mathrm{w}$ okresie dekoniunktury mogą być rozwiązania związane $\mathrm{z}$ wprowadzonym w 2009 roku do polskiego prawa gospodarczego pojęciem upadłości konsumenckiej. Stanowią one pewnego rodzaju zabezpieczenie dla przedsiębiorstw na wypadek niewypłacalności ich dłużników. Dotyczą one upadłości osoby fizycznej nie będącej przedsiębiorcą, która stała się niewypłacalna na skutek wyjątkowych i niezależnych od niej okoliczności. Jeżeli po przeprowadzeniu likwidacji masy upadłości (np. sprzedaży domu) i zaspokojeniu wierzycieli pozostaną niespłacone długi, sąd, na wniosek upadłego, orzeknie o planie ich spłat, których zakres będzie zależał od zarobków dłużnika, wysokości wierzytelności i możliwości ich zaspokojenia. Sąd może jednak ustalić warunki spłaty bardziej korzystne dla wierzycieli, jeżeli zażąda tego wierzyciel. W przypadku niespodziewanej poprawy sytuacji materialnej upadłego (jednak nie mającej związku z jego aktywnością zawodową lub gospodarczą) sąd będzie mógł zwiększyć wysokość spłacanych zobowiązań. W myśl przyjętych rozwiązań ochrona wierzycieli polega również na tym, że podczas spłaty długu niewypłacalni dłużnicy nie mogą dokonywać czynności przekraczających zakres zwykłego zarządu oraz są zobowiązani do składania corocznych sprawozdań o wykonaniu planu spłat, osiągniętych przychodach i zwiększeniu majątku. W przypadku niestosowania się upadłego dłużnika do tych zasad i niedokonywaniu przez niego spłat sąd może umorzyć postępowanie upadłościowe. Oznacza to, że dłużnik będzie musiał uregulować swoje zobowiązania na ogólnych zasadach.

Zmiany w prawie dokonane w 2009 roku mające na celu pobudzenie aktywności inwestycyjnej zostały zawarte m.in. w nowej ustawie o partnerstwie publiczno-prywatnym. Do najistotniejszych rozwiązań upraszczających współpracę podmiotów sektora prywatnego i publicznego wprowadzonych 
przez tę ustawę należy zaliczyć: odstąpienie od konieczności sporządzania kosztownych analiz przed rozpoczęciem współpracy, pozostawienie swobody wyboru odnośnie do przedmiotu partnerstwa, a także ograniczenie wymogu uzyskania zgody Ministra Finansów na realizację przedsięwzięć jedynie do tych, które wiążą się z zaangażowaniem środków budżetowych $\mathrm{w}$ wysokości przekraczającej $100 \mathrm{mln}$ zł. W przypadku konieczności uzyskania takiej zgody, Minister Finansów na jej wydanie ma 6 tygodni (poprzednia ustawa o partnerstwie publiczno-prywatnym na wydanie zgody przewidywała 60 dni). Ważną zmianą wprowadzoną przez ustawę o partnerstwie publicznoprywatnym jest także możliwość finansowania przedsięwzięć realizowanych w ramach takiego partnerstwa ze środków unijnych dostępnych w ramach realizowanych w Polsce programów operacyjnych. Oznacza to, że inwestycje ważne dla rozwoju społeczno-gospodarczego kraju, angażujące potencjał prywatnej przedsiębiorczości i mobilizujące zasoby polskich instytucji publicznych zyskały dodatkowe źródło finansowania. Wraz z innymi zmianami w zakresie zasad realizacji przedsięwzięć w formule partnerstwa publicznoprywatnego tworzy to korzystne warunki dla wzrostu liczby tych przedsięwzięć, a tym samym dla intensyfikacji aktywności inwestycyjnej przedsiębiorstw.

W 2009 roku w związku z trudną sytuacją ekonomiczną w Polsce będącą skutkiem światowego kryzysu finansowego, oprócz zmian zaplanowanych w ramach „Pakietu na rzecz przedsiębiorczości”, wprowadzono również rozwiązania określane mianem „Pakietu antykryzysowego”, zawarte w Ustawie z dnia 1 lipca 2009 roku o łagodzeniu skutków kryzysu ekonomicznego dla pracowników i przedsiębiorców (Dz.U. 2009, Nr 125, poz. 1035 z późn. zm.). Mają one na celu przede wszystkim umożliwienie przedsiębiorcom dostosowanie kosztów pracy do trudnej sytuacji ekonomicznej, a także złagodzenie skutków kryzysu gospodarczego odczuwanych przez pracowników. Ustawa przewiduje, że przedsiębiorca, który odczuwa przejściowe trudności finansowe może obniżyć pracownikom wymiar czasu pracy (do połowy pełnego wymiaru czasu pracy), a także proporcjonalnie obniżyć wynagrodzenie za pracę na okres maksymalnie 6 miesięcy, bez konieczności dokonywania wypowiedzenia zmieniającego. Może oprócz tego skorzystać z przestoju ekonomicznego. W czasie przestoju, trwającego łącznie maksymalnie pół roku, pracownicy niewykonujący pracy mają zapewnione wynagrodzenie na poziomie co najmniej minimalnego wynagrodzenia. Udział państwa w tym wynagrodzeniu stanowi równowartość zasiłku dla bezrobotnych. Przedsiębiorcy mogą liczyć również na pomoc państwa w opłaceniu składek pracowników na ubezpieczenie społeczne w części płatnej przez pracodawcę. Przewidziano również możliwość renegocjacji warunków 
spłaty należności Funduszu Gwarantowanych Świadczeń Pracowniczych powstałych przed 30 czerwca 2008 roku oraz dofinansowania pracownikom kosztów szkoleń lub studiów podyplomowych (pod warunkiem utworzenia funduszu szkoleniowego) ${ }^{6}$.

Ponadto, ustawa wprowadziła nowe regulacje w zakresie organizacji czasu pracy, którymi objęci są wszyscy przedsiębiorcy, niezależnie od ich sytuacji finansowej. Mogą oni wydłużyć okres rozliczeniowy czasu pracy do 12 miesięcy. W tym okresie miesięczne wynagrodzenie pracownika nie może być niższe niż minimalne wynagrodzenie za pracę. Możliwe jest także wprowadzenie elastycznego czasu pracy oznaczającego ustalenie różnych godzin rozpoczynania i kończenia pracy przez pracowników. W zakresie umów na czas określony wprowadzono ograniczenie w postaci maksymalnie 24-miesięcznego okresu trwania tych umów. Kolejną umową na czas określony jest umowa zawarta przed upływem 3 miesięcy od rozwiązania lub wygaśnięcia poprzedniej umowy zawartej na czas określony. Ponadto, umowa na czas określony automatycznie przechodzi w umowę na czas nieokreślony, gdy łączny czas przepracowany na umowach terminowych przekroczy 24 miesiące.

\section{REALIZACJA „PAKIETU NA RZECZ PRZEDSIĘBIORCZOŚCI” W 2010 ROKU}

W 2010 roku do ważniejszych zmian, z punktu widzenia ograniczania skutków kryzysu gospodarczego, wprowadzonych w ramach realizacji „Pakietu na rzecz przedsiębiorczości” należy zaliczyć możliwość zgłoszenia do biur informacji gospodarczej przez każdego wierzyciela, zarówno przedsiębiorcę, jak i osobę fizyczną, danych swojego dłużnika (tabela 3). Poszerzeniu uległ więc krąg podmiotów uprawnionych do współpracy z biurem informacji gospodarczej, co należy uznać za element zwiększający bezpieczeństwo obrotu gospodarczego w Polsce. Wiążą się z tym bowiem większe możliwości sprawdzenia wiarygodności partnera biznesowego. Informacje te są szczególnie cenne w okresie wzrostu liczby przedsiębiorstw i osób fizycznych przeżywających problemy z utrzymaniem płynności finansowej i stojących w obliczu braku możliwości regulowania zobowiązań.

7 Do końca 2010 r. pomoc dla przedsiębiorców dotkniętych skutkami kryzysu była udzielana w formie pomocy publicznej na zasadach przyjętych w UE. W 2011 r. jest udzielana jako pomoc de minimis. 
Tabela 3. Zmiany w ustawach określających zasady prowadzenia działalności gospodarczej w Polsce wprowadzone w ramach realizacji „Pakietu na rzecz przedsiębiorczości” w 2010 r.

\begin{tabular}{|c|c|}
\hline WYSZCZEGÓLNIENIE & NAJWAŻNIEJSZE ZMIANY \\
\hline $\begin{array}{c}\text { Ustawa o } \\
\text { udostępnianiu } \\
\text { informacji gospodarczych } \\
\text { i wymianie } \\
\text { danych gospodarczych }\end{array}$ & $\begin{array}{l}\text { - wzmocnienie bezpieczeństwa obrotu gospodarczego poprzez m.in. stworzenie ka- } \\
\text { talogu otwartego wierzycieli uprawnionych do współpracy z biurem informacji go- } \\
\text { spodarczej (BIG) oraz rozszerzenie katalogu tytułów prawnych uprawniających do } \\
\text { przekazania informacji gospodarczych do BIG, } \\
\text { - uzależnienie zgłoszenia dłużnika do biura informacji gospodarczej od wymagalno- } \\
\text { ści należności (zgłoszenie dłużnika będącego konsumentem może nastąpić, gdy } \\
\text { łączna kwota wymagalnych zobowiązań wobec wierzyciela przekroczy } 200 \text { zł oraz } \\
\text { zobowiązanie jest wymagalne od } 60 \text { dni; w przypadku dłużników nie będących } \\
\text { konsumentami do zgłoszenia uprawnia m.in. łączna kwota wymagalnych zobowią- } \\
\text { zań dłużnika wynosząca co najmniej } 500 \text { zł, która jest wymagalna od co najmniej } \\
60 \text { dni, } \\
\text { - ułatwienie przekazywania do biur informacji gospodarczej danych o wywiązywa- } \\
\text { niu się ze zobowiązań, } \\
\text { - uproszczenie współpracy pomiędzy biurami informacji gospodarczej i biurem infor- } \\
\text { macji kredytowej oraz podobnymi instytucjami działającymi w krajach UE, }\end{array}$ \\
\hline $\begin{array}{c}\text { Ustawa } \\
\text { o świadczeniu usług } \\
\text { na terytorium } \\
\text { Rzeczypospolitej Polskiej }\end{array}$ & $\begin{array}{l}\text { - wprowadzenie możliwości czasowego świadczenia usług na terytorium RP bez ko- } \\
\text { nieczności uzyskania wpisu do Krajowego Rejestru Sądowego lub ewidencji dzia- } \\
\text { łalności gospodarczej, } \\
\text { - wprowadzenie zakazu nakładania wymogów ograniczających korzystanie z usług } \\
\text { świadczonych przez usługodawcę (m.in. dotyczących obowiązku uzyskania zezwo- } \\
\text { lenia na korzystanie z usługi, a także wprowadzających dyskryminację w zakresie } \\
\text { przyznawania pomocy finansowej i dyskryminację ze względu na pochodzenie lub } \\
\text { miejsce zamieszkania), } \\
\text { - wprowadzenie instytucji domniemania zgody administracji publicznej, } \\
\text { - wprowadzenie pojedynczych punktów kontaktowych, w których przedsiębiorca - } \\
\text { polski i zagraniczny - może załatwiać wszystkie sprawy rejestracyjne i informacyjne, } \\
\text { - określenie jednolitych zasad wykonywania działalności usługowej oraz zasad } \\
\text { współpracy administracyjnej z właściwymi organami państw członkowskich UE } \\
\text { i państw EOG nienależących do UE, }\end{array}$ \\
\hline
\end{tabular}

Źródło: Ministerstwo Gospodarki, http://www.mg.gov.pl; Ustawa z dnia 9 kwietnia 2010 r. o udostępnianiu informacji gospodarczych i wymianie danych gospodarczych, Dz.U. 2010, Nr 81, poz. 530; Ustawa z dnia 4 marca 2010 r. o świadczeniu usług na terytorium Rzeczypospolitej Polskiej, Dz.U. 2010, Nr 47, poz. 278.

\section{ZAKOŃCZENIE}

W latach 2008-2010 w polskim prawie gospodarczym wprowadzono zmiany mające na celu uproszczenie środowiska regulacyjnego przedsiębiorczości, polegające na ułatwieniu rozpoczynania i prowadzenia działalności gospodarczej, stymulowaniu aktywności inwestycyjnej przedsiębiorstw oraz zwiększeniu bezpieczeństwa obrotu gospodarczego.

Do najważniejszych zmian w zakresie rozpoczynania i prowadzenia działalności gospodarczej należy zaliczyć: 
— wprowadzenie tzw. ,jednego okienka”, dzięki któremu osoby zamierzające rozpocząć działalność gospodarczą mogą złożyć jeden wniosek o rejestrację tej działalności, dopełniając tym samym wszelkich formalności rejestracyjnych;

- możliwość zawieszenia działalności gospodarczej na okres od miesiąca do 2 lat bez konieczności ponoszenia w tym czasie kosztów funkcjonowania przedsiębiorstwa związanych m.in. z uiszczaniem podatków, opłacaniem zaliczek na podatki i składek ubezpieczeniowych;

- podniesienie progu przychodów zobowiązujących do prowadzenia pełnej księgowości z 800 tys. euro do 1,2 mln euro;

- możliwość kwartalnego opłacania zaliczek na podatek dochodowy przez tzw. małych podatników;

- możliwość dokonywania rozliczeń i prowadzenia rachunków w walutach wymienialnych;

- obniżenie minimalnego kapitału zakładowego w spółkach z ograniczoną odpowiedzialnością i spółkach akcyjnych.

Wśród zmian, które mogą przyczynić się do zwiększenia aktywności inwestycyjnej przedsiębiorstw największe znaczenie mają:

- możliwość zaliczania do kosztów podatkowych wydatków poniesionych na inwestycje do wysokości 100 tys. euro w postaci jednorazowo dokonywanych odpisów amortyzacyjnych;

- zwiększenie dostępu do kredytu technologicznego;

- powiększenie powierzchni specjalnych stref ekonomicznych i wprowadzenie możliwości dokonywania zmian w zezwoleniach na prowadzenie działalności gospodarczej na terenie strefy;

- uproszczenie zasad realizowania przedsięwzięć inwestycyjnych w ramach partnerstwa publiczno-prywatnego, w tym umożliwienie finansowania tych przedsięwzięć ze środków unijnych w ramach programów operacyjnych.

Do poprawy bezpieczeństwa obrotu gospodarczego w Polsce moga przyczynić się zmiany dotyczące:

- ochrony wierzycieli niewypłacalnych dłużników będących osobami fizycznymi spełniającymi kryteria upadłości konsumenckiej;

- poszerzenia kręgu podmiotów uprawnionych do współpracy z biurami informacji gospodarczej - mogą to być zarówno przedsiębiorcy, jak i osoby fizyczne.

Zmiany te, będąc elementem reformy regulacji zaplanowanej na lata 2008-2011, zbiegły się w czasie ze spowolnieniem gospodarczym w Polsce spowodowanym światowym kryzysem ekonomicznym. W takich warunkach mogą one stanowić szczególnie istotny czynnik ułatwiający prowadzenie dzia- 
łalności gospodarczej, a niekiedy nawet umożliwiający przetrwanie przedsiębiorstw na rynku. Mogą także być bodźcem stymulującym aktywność inwestycyjną przedsiębiorstw, przyczyniając się tym samym do przenoszenia impulsów rozwojowych na całą gospodarkę.

Wprowadzenie tych rozwiązań należy ocenić pozytywnie. Mają one na celu uproszczenie zasad związanych z prowadzeniem działalności gospodarczej, a tym samym są czynnikiem poprawy jakości otoczenia instytucjonalnego przedsiębiorczości w Polsce. Ocena ich wpływu na funkcjonowanie podmiotów gospodarczych nie jest jednak zadaniem łatwym. Efekty zmian w prawie będzie można zmierzyć po upływie pewnego czasu od momentu ich wprowadzenia. Poza tym, zachowania mikropodmiotów na rynku nie zależą wyłącznie od ram prawnych konstytuujących zasady ich funkcjonowania. Mają na nie wpływ także inne czynniki, m.in. instytucje nieformalne, koniunktura na rynku światowym oraz klimat przedsiębiorczości w regionie. Kluczowe dla oceny wpływu zmian w prawie gospodarczym na funkcjonowanie przedsiębiorstw jest zbadanie, w jakim stopniu zmiany te zostały rzeczywiście wprowadzone, a w jakim pozostały tzw. martwymi przepisami, niewykonalnymi z uwagi na brak możliwości technicznych i organizacyjnych. Duże znaczenie ma również to, ile niekorzystnych dla przedsiębiorców przepisów pozostało $\mathrm{w}$ aktach prawnych, stanowiąc utrudnienie w prowadzeniu działalności gospodarczej i będąc barierą hamującą rozwój przedsiębiorczości w Polsce.

\section{BIBLIOGRAFIA}

Famielec J., Kryzys finansowy a rozwój przedsiębiorczości, [w:] K. Jaremczuk (red.), Uwarunkowania przedsiębiorczości. Różnorodnośc i jedność, t. 2, Wydawnictwo Państwowej Wyższej Szkoły Zawodowej im. prof. Stanisława Tarnowskiego w Tarnobrzegu, Tarnobrzeg 2010.

Krajowy Program Reform na lata 2008-2011 na rzecz realizacji Strategii Lizbońskiej, http://www.mg.gov.p1/NR/rdonlyres/ ED3609C2-1747-4125-98B1C23D09115D94/49494/KrajowyProgramReformna lata20082011.pdf, Ministerstwo Gospodarki 2008 (stan na dzień 15.03.2011).

Raport z realizacji dziatan Reformy Regulacji w 2009 roku, http://www.mg.gov.pl/files/upload/8668/publikacja_5.pdf, Ministerstwo Gospodarki 2010 (stan na dzień 15.03.2011).

Safin K., Uwarunkowania rozwoju przedsiębiorczości - próba systematyzacji, [w:] K. Jaremczuk (red.), Uwarunkowania przedsiębiorczości, Wydawnictwo Państwowej Wyższej Szkoły Zawodowej im. prof. Stanisława Tarnowskiego w Tarnobrzegu, Tarnobrzeg 2004. 
Ustawa z dnia 10 lipca 2010 r. o zmianie ustawy o swobodzie dziatalności gospodarczej oraz o zmianie niektórych innych ustaw, Dz.U. 2008, Nr 141, poz. 888.

Ustawa z dnia 10 lipca 2008 r. o zmianie ustawy o rachunkowości, Dz.U. 2008, Nr 144, poz. 900.

Ustawa z dnia 7 listopada 2008 r. o zmianie ustawy - Ordynacja podatkowa oraz niektórych innych ustaw, Dz.U. 2008, Nr 209, poz. 1318.

Ustawa z dnia 6 listopada 2008 r. o zmianie ustawy o podatku dochodowym od osób fizycznych, ustawy o podatku dochodowym od osób prawnych oraz niektórych innych ustaw, Dz.U. 2008, Nr 209, poz. 1316.

Ustawa z dnia 7 listopada 2008 r. o zmianie ustawy o izbach gospodarczych, Dz.U. 2008, Nr 216, poz. 1369.

Ustawa z dnia 23 października 2008 r. o zmianie ustawy - Kodeks cywilny oraz ustawy - Prawo dewizowe, Dz.U. 2008, Nr 228, poz. 1506.

Ustawa z dnia 23 października 2008 r. o zmianie ustawy Kodeks spótek handlowych, Dz.U. 2008, Nr 217, poz. 1381.

Ustawa z dnia 30 maja 2008 r. o niektórych formach wspierania dziatalności innowacyjnej, Dz.U. 2008, Nr 116, poz. 730.

Ustawa z dnia 30 maja 2008 r. o zmianie ustawy o specjalnych strefach ekonomicznych, Dz.U. 2008 nr 118 poz. 746.

Ustawa z dnia 19 grudnia 2008 r. o zmianie ustawy o swobodzie dziatalności gospodarczej oraz o zmianie niektórych innych ustaw, Dz.U. 2009, Nr 18, poz. 97.

Ustawa z dnia 5 grudnia 2008 r. o zmianie ustawy Prawo upadtościowe i naprawcze oraz ustawy o kosztach sadowych w sprawach cywilnych, Dz.U. 2008, Nr 234, poz. 1572.

Ustawa z dnia 19 grudnia 2008 r. o partnerstwie publiczno-prywatnym, Dz.U. 2009, $\mathrm{Nr} 19$, poz. 100.

Ustawa z dnia 7 maja 2009 r. o towarach paczkowanych, Dz.U. 2009, Nr 91, poz. 740. Ustawa z dnia 17 lipca 2009 r. o praktykach absolwenckich, Dz.U. 2009, Nr 127, poz. 1052. Ustawa z dnia 9 kwietnia 2010 r. o udostępnianiu informacji gospodarczych $i$ wymianie danych gospodarczych, Dz.U. 2010, Nr 81, poz. 530.

Ustawa z dnia 4 marca 2010 r. o świadczeniu ustug na terytorium Rzeczypospolitej Polskiej, Dz.U. 2010, Nr 47, poz. 278.

Ustawa z dnia 1 lipca 2009 r. o tagodzeniu skutków kryzysu ekonomicznego dla pracowników i przedsiębiorców, Dz.U. 2009, Nr 125, poz. 1035 z późn. zm.

\section{PRAWNE UWARUNKOWANIA PRZEDSIĘBIORCZOŚCI W POLSCE W OKRESIE ŚWIATOWEGO KRYZYSU EKONOMICZNEGO}

\section{STRESZCZENIE}

Przedsiębiorczość należy do kluczowych czynników rozwoju społeczno-gospodarczego oraz przeciwdziałania skutkom kryzysu ekonomicznego. Sposobem na uaktywnienie przedsiębiorczości w okresie spowolnienia gospodarczego, charakteryzującym się 
stosunkowo niskimi kosztami w porównaniu do możliwych do osiągnięcia rezultatów, jest wprowadzanie zmian w prawie gospodarczym, polegających na upraszczaniu środowiska regulacyjnego przedsiębiorczości. Celem poznawczym artykułu jest identyfikacja i charakterystyka najistotniejszych zmian wprowadzonych w prawie gospodarczym w Polsce w latach 2008-2010. Celem aplikacyjnym jest natomiast zaprezentowanie możliwości wykorzystania tych zmian przez przedsiębiorstwa w Polsce doświadczające trudności w funkcjonowaniu na rynku, będących skutkiem światowego kryzysu ekonomicznego.

\title{
LEGAL CONDITIONS OF ENTREPRENEURSHIP IN POLAND DURING GLOBAL ECONOMIC CRISIS
}

\author{
SUMMARY
}

Entrepreneurship is one of the key factors of socio-economic development and one of the key factors for countering the results of economic crisis. During the economic crisis, the way for enabling entrepreneurship, which has a relatively low costs in comparison to effects that may be achieved, results in changes in economic law relying on simplification in regulatory entrepreneurship environment. The cognitive aim of the paper is identifying and characterizing the most important changes in Polish economic law making in the period of 2008-2010. The practice aim of the paper is presenting the way in which the changes may be used by the enterprises in Poland which encounter problems which result from the global economic crisis. 
